\title{
Ureterocele with impacted stone
}

\author{
Kalpesh Mahesh Parmar (1) , Pawan Sharma, Subhajit Mandal, Santosh Kumar
}

Urology, Post Graduate Institute of Medical Education and Research, Chandigarh, India

\section{Correspondence to}

Dr Kalpesh Mahesh Parmar; kalpesh010385@gmail.com

Accepted 17 June 2020

\section{DESCRIPTION}

A 24-year-old man presented with urinary frequency, urgency and post-void dribbling of 4 weeks duration. Patient had no history of haematuria, urinary retention, dysuria, graveluria, fever or flank pain. His past medical history and family history were insignificant. General physical examination and systemic examination were normal. Ultrasound of the abdomen showed normal bilateral kidneys and $3 \times 2 \mathrm{~cm}$ mobile echogenic shadow in base of the urinary bladder suggestive of bladder stone. X-ray of kidney, ureter and bladder confirmed a radioopaque hyperdense stone in the pelvis (figure 1). Routine work up including haemogram, renal function and serum electrolytes were within normal limits. Urinalysis revealed six to eight pus cells and culture was sterile. Uroflowmetry showed Q $\max$ of $12.2 \mathrm{~mL} / \mathrm{sec}$ for voided volume of $260 \mathrm{~mL}$. Patient was counselled for endoscopic cystolithotripsy under regional anaesthesia. On endoscopy, urinary bladder showed no evidence of stone. To our surprise, left ureteric orifice was dilated and seen as an outpouching inside the urinary bladder with stone projecting from the lumen suggestive of ureterocele (figure 2A). Using 26 French resectoscope and Collins knife, inverted U shaped incision was given and stone extracted into the urinary bladder (figure 2B). Stone was fragmented with holmium laser (365-micron fibre, Energy - 1 Joule, Frequency - 15 hertz/sec) and fragments were removed with Ellik evacuator. The ureteric orifice

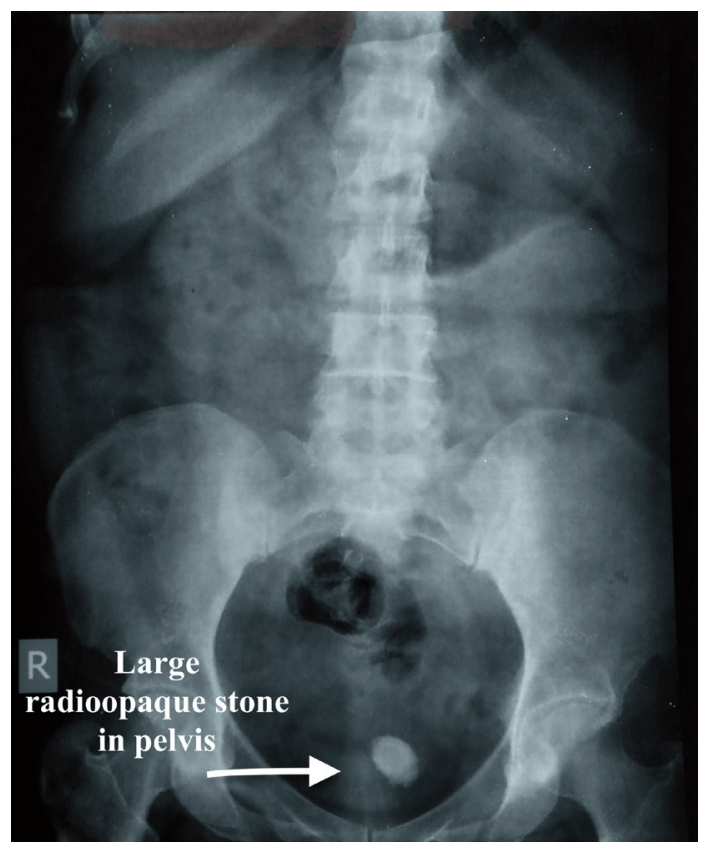

Figure 1 Plain X-ray of kidney, ureter and bladder showing $3 \times 2 \mathrm{~cm}$ dense radio-opaque stone in the pelvis.

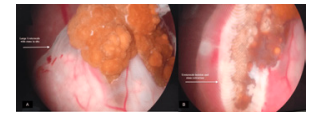

Figure 2 (A) Intraoperative cystoscopy image showing outpouching of left ureter with impacted stone projecting from the orifice. (B) Ureteric orifice incision using Collins knife to extract the impacted stone.

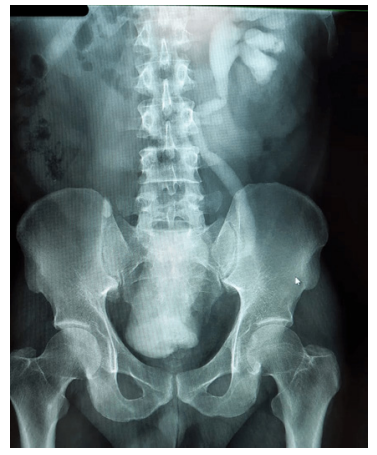

Figure 3 Micturating cystogram showing left grade 4 vesicoureteric reflux.

was widely open and showed no residual stone. A 14 French Foley catheter was placed. Postoperative period was uneventful and catheter was removed after 2 days. On follow-up, micturating cystogram showed grade 4 vesicoureteric reflux (figure 3). Patient is asymptomatic and urine culture is sterile at 1-year follow-up.

Contributors KMP and PS collected data and drafted the initial manuscript, SM collected images and edited them, KMP revised

\section{Patient's perspective}

I am very thankful to whole team of doctors and hospital staff for appropriate intervention and management of my disease.

\section{Learning points}

- Ureterocele with stone impacted at distal end may mimic as urinary bladder stone.

- Ultrasound and plain X-ray of the pelvis can be deceptive. $\mathrm{CT}$ is essential before surgical intervention to confirm the diagnosis and rule out any anomalies.

- Correct diagnosis is indispensable to prognosticate the patient about the disease and its sequelae. 


\section{Images in...}

the manuscript, SK gave critical comments. All authors have read and approved the manuscript.

Funding The authors have not declared a specific grant for this research from any funding agency in the public, commercial or not-for-profit sectors.

Competing interests None declared.
Patient consent for publication Obtained.

Provenance and peer review Not commissioned; externally peer reviewed.

\section{ORCID iD}

Kalpesh Mahesh Parmar http://orcid.org/0000-0003-3891-4089

Copyright 2020 BMJ Publishing Group. All rights reserved. For permission to reuse any of this content visit https://www.bmj.com/company/products-services/rights-and-licensing/permissions/

BMJ Case Report Fellows may re-use this article for personal use and teaching without any further permission.

Become a Fellow of BMJ Case Reports today and you can:

- Submit as many cases as you like

- Enjoy fast sympathetic peer review and rapid publication of accepted articles

Access all the published articles

Re-use any of the published material for personal use and teaching without further permission

\section{Customer Service}

If you have any further queries about your subscription, please contact our customer services team on +44 (0) 2071111105 or via email at support@bmj.com.

Visit casereports.bmj.com for more articles like this and to become a Fellow 